\section{JURNAL ABDIMAS

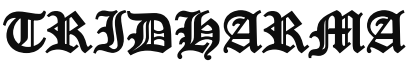

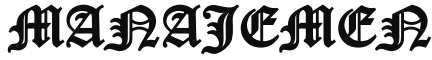

\title{
PENGENALAN STANDAR ISO DALAM MENINGKATKAN KINERJA SDM PADA YAYASAN PONDOK PESANTREN DAN PANTI ASUHAN NURUL IHSAN
}

\author{
Jamaludin*, Suharni Rahayu, Sinta Sulistiani, Hendri Prasetyo, Gos Ishak \\ Dosen Ekonomi Fakultas Ekonomi Universitas Pamulang \\ Email dosen01020@unpam.ac.id, dosen01876@unpam.ac.id, \\ dosen00806@unpam.ac.id, dosen00595@unpam.ac.id
}

\begin{abstract}
ABSTRAK
Pengabdian ini berjudulPengenalan Standar ISO Dalam Meningkatkan Kinerja Sdm Pada Yayasan Pondok Dan Panti Asuhan Nurul Ihsan. Penerapan ISO 9001:2008 sebagai perbaikan sistem manajemen mutu dalam organisasi akan memberikan dampak positif pada sikap individu pegawai yaitu kinerja pegawai. Kegiatan Pengabdian Kepada Masyarakat ini bertujuan untuk memperkenalkan ISO dalam meningkatkan kinerja SDM pada Pondok Pesanteren Nurul Ihsan, dan untuk mengetahui pengaruh implementasi Sistem Manajemen Mutu ISO 9001:2008 terhadap kinerja SDM Nurul Ihsan.

Adapun metode yang dilakukan dalam PKM ini adalah Presentation dengan memberikan presentasi materi yang berkaitan dengan ISO, Metode Discuss dengan cara memberikan kesempatan kepada mitra memberikan pertanyaan-pertanyaan yang berkaitan dengan tema PKM, metode Case dengan cara memberikan informasi terkait dengan kasus keberhasilan lembaga yang sudah menerapkan ISO, dan metode Evaluation dengan cara melakukan evaluasi terhadap apa yang sudah dilakukan oleh pihak mitra dan memberikan solusi apa yang akan dilakukan jika mau menerapkan system manajemen mutu ISO 9001:2008.

Hasil dari PKM ini dapat memberikan pemahaman kepada Pondok Pesantren Nurul Ihsan dalam menerapkan dan mengimplementasikan ISO 9001: 2008 kedepannya.Implementasi ISO 9001:2008 sangat dipengaruhi oleh sumber daya manusia, yaitu pegawai. Pegawai merupakan sumber daya penting dalam Implementasi ISO 9001:2008 itu sendiri karena pegawailah yang merencanakan, mengimplementasikan dan mengevaluasi keefektifan pelaksanaan ISO 9001:2008 dalam meningkatkan kinerja pegawai. Penerapan ISO 9001:2008 sebagai perbaikan sistem manajemen mutu dalam organisasi akan memberikan dampak positif pada sikap individu pegawai yaitu kinerja pegawa Sistem Manajemen Mutu memberikan jaminan mutu terhadap semua proses yang dijalankan, jika sebuah produk baik barang maupun jasa dari sisi proses sudah berkualitas maka output yang dihasilkan secara tidak langsung dapat dikatakan berkualitas atau bermutu. Hal ini disebabkan karena sistem manajemen mutu merupakan pendekatan yang dilakukan dari sisi proses, dimana pendekatan ini memiliki keterkaitan dengan pendekatan sistem dan pendekatan fakta yang berfungsi untuk mengukur keberhasilan program secara menyeluruh. Pendekatan proses ini tidak terlepas dari masukan (input) dan hasil proses (output). Pendekatan proses dalam SMM ISO 9001 memberikan dampak kepada organisasi terutama dalam kinerja. Salah satu faktor yang dapat berpengaruh terhadap pencapaian peningkatan kepuasan kerja pegawai adalah dengan melakukan perbaikan sistem manajemen mutu organisasi.
\end{abstract}

Kata Kunci: Manajemen Mutu, ISO 9001:2008 


\section{JURNAL ABDIMAS

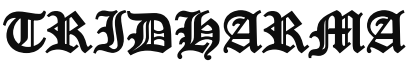

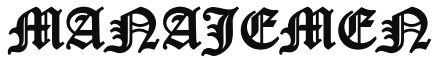

P-ISSN 2615-6849, E-ISSN 2716-070X

Jurnal ABDIMAS Vol. 1,No.2, Mei 2020,Hal(42-55)

@ Prodi Manajemen Fakultas Ekonomi Universitas Pamulang

Email: abdimasjurnal.unpam@gmail.com Telp: (021) 741-2566

\begin{abstract}
ABSTRAC
This dedication is entitled Introduction of ISO Standards in Improving the Performance of Human Resources at the Nurul Ihsan Pondok And Orphanage Foundation. The application of ISO 9001: 2008 as an improvement in the quality management system in an organization will have a positive impact on the attitudes of individual employees, namely employee performance. This Community Service activity aims to introduce ISO in improving HR performance at Nurul Ihsan Islamic Boarding School, and to determine the effect of the implementation of the ISO 9001: 2008 Quality Management System on HR Nurul Ihsan's performance.

The method used in this PKM is the Presentation by presenting material related to ISO, the Discussion Method by providing an opportunity for partners to give questions related to the PKM theme, the Case method by providing information related to the case of the success of the institution that has implemented ISO, and the Evaluation method by evaluating what has been done by partners and providing solutions to what will be done if you want to implement an ISO 9001: 2008 quality management system.

The results of this PKM can provide understanding to Nurul Ihsan Islamic Boarding School in implementing and implementing ISO 9001: 2008 going forward. The implementation of ISO 9001: 2008 is strongly influenced by human resources, namely employees. Employees are an important resource in the implementation of ISO 9001: 2008 itself because it is employees who plan, implement and evaluate the effectiveness of implementing ISO 9001: 2008 in improving employee performance. The implementation of ISO 9001: 2008 as an improvement in the quality management system in an organization will have a positive impact on the attitudes of individual employees, namely the performance of employees. indirectly produced can be said to be of quality or quality. This is because the quality management system is an approach that is carried out in terms of the process, where this approach has a relationship with the system approach and fact approach that serves to measure the overall success of the program. This process approach is inseparable from the input (input) and process results (output). The process approach in the ISO 9001 QMS has an impact on organizations especially in performance. One of the factors that can influence the achievement of employee job satisfaction is to improve the organization's quality management system.
\end{abstract}

\title{
Keywords: Quality Management, ISO 9001: 2008
}

\section{PENDAHULUAN}

Perubahan merupakan sunnatullah. Allah SWT dalam Al-Qur'an surat ArRa'd ayat 11 berfirman: "Sesungguhnya Allah tidak merobah keadaan sesuatu kaum sehingga mereka merobah keadaan yang ada pada diri mereka sendiri". Dalam Ilmu Balaghah, ayat di atas merupakan bentuk ikhbariyyah (informatif), karena berkaitan dengan berita Allah kepada manusia tentang pentingnya perubahan. Dalam Tafsir Al-Hawi 'ala AlJalalain, makna innallâha lâ yughayyiru mâ biqaumin (sesungguhnya Allah tidak mengubah apa yang ada pada suatu kaum) adalah $l \hat{a}$ ni'matahu (tidak mencabut dari mereka nikmatnya). Sedangkan ayat hattâ yughayyirû mâ bianfusihim (kecuali mereka mengubah apa yang ada pada diri mereka) maknanya man al-khâlati aljamîlati bi al-ma'shiyati (dari sifat-sifat yang bagus dan terpuji menjadi perbuatan maksiat). Dalam ilmu Bayan nya Al-Jabiri ayat ini termask Bayani Mauhuban (dapat diterima) atau Bayani Maksuban (yang diusahakan dan ditanggapi). Sebab, teks ayat tersebut berbentuk khabar yang sudah jelas kebenarannya tidak diragukan lagi untuk dilaksanakan.

Ayat di atas bisa menjadi driving force bagi pimpinan pesantren Nurul Ihsan dalam melakukan perubahan menuju 


\section{JURNAL ABDIMAS

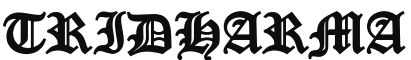

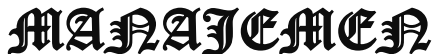

P-ISSN 2615-6849, E-ISSN 2716-070X

Jurnal ABDIMAS Vol. 1,No.2, Mei 2020,Hal(42-55)

@Prodi Manajemen Fakultas Ekonomi Universitas Pamulang

Email: abdimasjurnal.unpam@ gmail.com Telp: (021) 741-2566 perbaikan mutu pendidikan di Pondok Pesantren, terutama perubahan terhadap sistem kelembagaannya dan juga perubahan orientasi lulusannya. Artinya, ke depan, dalam rangka perbaikan mutu pesantren, pimpinan perlu melakukan perbaikan terhadap mutu kelembagaannya yakni dengan cara menerima kehadiaran pendidikan formal dan vocasional ke dalam sistem pendidikan pesantren. Maksudnya, di dalam lingkungan pesantren tidak hanya pembelajaran salafiyah, akan tetapi di dalamnya pesantren perlu menyelenggarakan pendidikan formal dan vocasional untuk bersaing dengan lembaga pendidikan lainnya. Hal ini perlu dilakukan demi menjaga eksistensi pesantren ke depan. Sebab, pada masa mendatang akan terjadi perubahan orientasi masyarakat dalam memilih lembaga pendidikan. Pada masa mendatang masyarakat lebih memilih lembaga pendidikan yang mampu mendidik siswanya memiliki ijazah formal dan memiliki keterampilan. Nah, pesantren tentu saja bisa dan memiliki kelebihan, karena pesantren memiliki keunggulan dalam pendidikan akhlaq. Kalau ini dilakukan, pada gilirannya nanti lulusan pesantren tidak hanya ahli agama (mutafaqqih fiddîn), akan tetapi juga lulusan yang memiliki kecerdasan pengetahuan (mutakallimin) dan sekaligus lulusan yang mampu berdiri sendiri (mutaqawwimin).

Jadi, salah satu terobosan dalam rangka peningkatan mutu pendidikan di pesantren adalah membuka penyelenggaraan pendidikan formal dan vocasional di lingkungan pendidikan pesantren, agar lulusannya menjadi ahli agama, memiliki kemampuan berfikir, dan sekaligus memiliki keterampilan untuk hidup mandiri di tengah masyarakat.

Dalam implementasinya di lapangan bisa menggunakan manajemen mutu modern seperti yang dikembangkan oleh Joseph M. Juran dan dipadukan dengan manajemen mutu khas pondok pesantren.
Dengan demikian, melihat berbagai permasalahan mendasar tersebutlah, Tim PKM dari Unpam hadir dalam memberikan pemahaman terkait manajemen mutu dan pengenala ISO. Dengan harapan dapat di implementasikan dalam keseharian Yayasan Pondok Pesantren dan Panti Asuhan Nurul Ihsan. Kegiatan PKM ini bertema "Pengenalan Standar ISO Dalam Meningkatkan Kinerja SDM Pada Yayasan Pondok Pesantren Dan Panti Asuhan Nurul Ihsan Kp. Momonggor, kel. Keranggan, Kec. Setu, Kota Tangerang Selatan".

\section{RUMUSAN MASALAH}

Melihat dari permasalahan diatas, maka adapun rumusan masalah dalam kegiatan PKM ini adala sebagai berikut:

1. Bagaimana standar mutu Yayasan Pondok Pesantren Dan Panti Asuhan Nurul Ihsan Kampung Mononggor?

2. Bagaimana Implementasi Standar ISO Dalam Meningkatkan Kinerja SDM Pada Yayasan Pondok Pesantren Dan Panti Asuhan Nurul Ihsan Kampung Mononggor?

3. Apa yang harus dilakukan oleh Yayasan Pondok Pesantren Dan Panti Asuhan Nurul Ihsan Kampung Mononggor jika mau menerapkan Standar ISO ?

\section{TUJUAN PELAKSANAAN}

Adapun tujuan dari PKM ini adalah sebagai berikut:

1. Untuk mengetahui standar pelayanan Yayasan Pondok Pesantren Dan Panti Asuhan Nurul Ihsan Kampung Mononggor.

2. Untuk mengetahui Implementasi Standar Iso Dalam Meningkatkan Kinerja SDM Pada Yayasan Pondok Pesantren Dan Panti Asuhan Nurul Ihsan Kampung Mononggor.

3. Untuk mengetahui yang harus dilakukan oleh Yayasan Pondok 


\section{JURNAL ABDIMAS

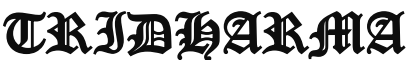

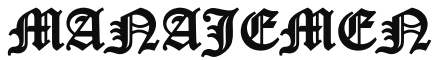

P-ISSN 2615-6849, E-ISSN 2716-070X

Jurnal ABDIMAS Vol. 1,No.2, Mei 2020,Hal(42-55)

@Prodi Manajemen Fakultas Ekonomi Universitas Pamulang

Email: abdimasjurnal.unpam@ gmail.com Telp: (021) 741-2566
Pesantren Dan Panti Asuhan Nurul Ihsan Kampung Mononggor jika mau menerapkan Standar ISO.

\section{TINJAUAN PUSTAKA}

1. Manajemen Mutu (Quality Management)

Manajemen mutu adalah sebuah sistem manajemen untuk mengawasi semua kegiatan dan tugas dalam suatu organisasi untuk memastikan bahwa produk dan layanan yang ditawarkan, serta sarana yang digunakan untuk mencapainya bersifat konsisten. Istilah bermutu sering diperbincangkan dalam kehidupan sehari-hari, umumnya digunakan dalam arti "bermutu baik", misalnya sekolah bermutu, pesantren bermutu, makanan bermutu atau pelayanan bermutu dan lain-lain. Dalam bahasa inggris juga demikian: "quality food quality service," jadi tidak selalu disebut kata "baik" atau " good" atau good quality". Dalam pemahaman umum, mutu berarti "sifat yang baik" atau " goodness". Tapi yang dimaksud dengan "sifat yang baik" tidak selalu jelas, tolok ukurnya perlu diteliti.

Dalam perbincangan sehari-hari, istilah "bermutu" umumnya digunakan dalam arti "bermutu baik", misalnya sekolah bermutu, makanan bermutu, atau pelayanan bermutu dan lain-lain. Menurut Suryadi (2009 : 18) Mutu dalam ari relatif, ukuran mutu adalah kebutuhan pelanggan. Dengan kata lain, pelanggan pada hakikatnya ikut menentukan mutu, jadi bukan hanya produsen yang menentukannya kebutuhan pelanggan berubah sesuai dengan perkembangan dan kebutuhan masyarakat. Sedangkan menurut Juran mengemukakan bahwa: Mutu adalah keseuaian dengan tujuan atau manfaatnya (J.M. Juran, 1995).

Adapun mutu dalam pendidikan dengan definisi yang relatif mempunyai dua aspek: a) pengukuran kemampuan lulusan sesuai dengan tujuan sekolah yang ditetapkan dalam kurikulum, b) pengukuran terhadap pemenuhan kebutuhan dan tuntutan pelanggan, yaitu orang tua siswa dan masyarakat (Hari, 2005)

Hal ini diperlukan untuk mencapai dan mempertahankan tingkat mutu yang diinginkan dalam organisasi. Termasuk di dalamnya penentuan kebijakan mutu, menciptakan dan menerapkan perencanaan dan jaminan kualitas, dan kontrol kualitas serta peningkatan kualitas. Jadi fokus sistem manajemen mutu tidak hanya pada produk dan kualitas layanan, tetapi juga pada cara untuk mencapainya sekaligus mempertahankannya.

\section{Komponen Utama Manajemen Mutu}

Manajemen mutu terdiri dari empat komponen utama, yang meliputi:

1. Perencanaan Kualitas - Proses mengidentifikasi standar kualitas yang relevan dengan proyek dan memutuskan bagaimana cara memenuhinya.

\section{Peningkatan Kualitas -} Perubahan yang disengaja dari suatu proses untuk meningkatkan kepercayaan atau keandalan hasil.

3. Kontrol Kualitas - Upaya berkelanjutan untuk menegakkan integritas dan keandalan proses dalam mencapai hasil.

4. Jaminan Kualitas - Tindakan sistematis atau terencana yang diperlukan untuk menawarkan keandalan yang memadai sehingga layanan atau produk tertentu akan memenuhi persyaratan yang telah ditentukan.

\section{Tujuan Manajemen Mutu}

Tujuan dari manajemen mutu adalah untuk memastikan bahwa semua bagian dalam organisasi bekerja bersama untuk meningkatkan proses, produk, layanan, dan budaya perusahaan untuk mencapai 


\section{JURNAL ABDIMAS

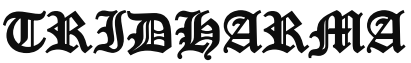

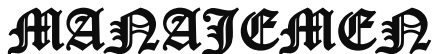

P-ISSN 2615-6849, E-ISSN 2716-070X

Jurnal ABDIMAS Vol. 1,No.2, Mei 2020,Hal(42-55)

@ Prodi Manajemen Fakultas Ekonomi Universitas Pamulang

Email: abdimasjurnal.unpam@ gmail.com Telp: (021) 741-2566 keberhasilan jangka panjang yang berasal dari kepuasan pelanggan.

Proses Manajemen Mutu

Pada proses manajemen mutu melibatkan kumpulan pedoman yang sudah dikembangkan oleh tim untuk memastikan bahwa produk dan layanan yang dihasilkan memiliki standar yang tepat atau sesuai dengan tujuan.

Aktivitas pada proses manajemen mutu dimulai ketika organisasi menetapkan target kualitas yang harus dipenuhi dan yang disepakati dengan pelanggan. Organisasi kemudian mendefinisikan bagaimana target akan diukur. Kemudian mengambil tindakan yang diperlukan untuk mengukur kualitas.Selanjutnya mengidentifikasi masalah kualitas yang muncul dan memulai perbaikan.Langkah terakhir melibatkan pelaporan tingkat keseluruhan kualitas yang dicapai. Proses ini memastikan bahwa kualitas dan desain produk serta layanan yang dihasilkan oleh tim sesuai dengan harapan pelanggan.

Metode peningkatan kualitas terdiri dari tiga komponen:, yaitu peningkatan kualitas produk, peningkatan kualitas proses, dan peningkatan kualitas berbasis orang. Jadi manajemen mutu merupakan gabungan dari semua fungsi manajemen yang dibangun berdasarkan konsep kualitas yang berorientasi pada kepuasan pelanggan.

\section{Manajemen Mutu ISO?}

Definisi dari ISO (International Organization for Standardization) adalah organisasi internasional untuk standardisasi terbesar di dunia yang berpusat di Jenewa, Swiss. ISO merupakan organisasi internasional non-pemerintah yang independen dengan keanggotaan 163 badan standar nasional, yang mana menyatukan para ahli untuk berbagi pengetahuan dan pengembangkan standar internasional yang relevan secara sukarela, berbasis konsensus, yang mendukung inovasi dan memberikan solusi untuk tantangan global.
Lembaga ISO didirikan pada tahun 1947, dan telah menerbitkan 22481 standar internasional yang mencakup hampir semua aspek teknologi dan bisnis. Perlu diketahui bahwa ISO menetapkan standarstandar internasional untuk dunia industrial dan komersial agar segala sesuatunya berfungsi dengan baik. Standar internasional ini memberikan spesifikasi kelas dunia bagi produk, layanan dan sistem, untuk memastikan kualitas, keamanan dan efisiensinya.ISO ini berperan penting dalam memfasilitasi perdagangan

internasional yang berdampak pada semua orang, di mana saja.

Standar Internasional berarti bahwa konsumen dapat memiliki keyakinan bahwa produk mereka aman, dapat diandalkan, dan berkualitas baik. Standar ISO yang sudah kita kenal antara lain tentang keselamatan di jalan, keselamatan mainan, dan kemasan medis yang aman, standarisasi ukuran kertas, kartu ATM Bank, jenis film fotografi dan lain-lain. Jadi dalam sistem manajemen mutu ISO, kualitas produk dan layanan, serta proses untuk mencapainya sekaligus mempertahankannya harus sesuai dengan standar ISO.

\section{Apa yang dimaksud dengan sertifikat ISO?}

Sertifikasi dapat menjadi alat yang berguna untuk menambah kredibilitas, dengan menunjukkan bahwa produk atau layanan Anda memenuhi harapan pelanggan Anda.Untuk beberapa industri, sertifikasi adalah persyaratan hukum atau kontrak.

Sertifikasi ISO adalah jaminan persetujuan dari pihak ke-3 yang dijalankan perusahaan terhadap salah satu sistem manajemen ISO yang diakui secara internasional. Sertifikasi dapat digunakan untuk tender bisnis sebagai bukti kredibilitas perusahaan dan juga untuk membuat kepercayaan pada klien potensial bahwa perusahaan dapat dipercaya.

Sebuah perusahaan/brand yang sudah mempunyai sertifikat ISO akan 


\section{JURNAL ABDIMAS

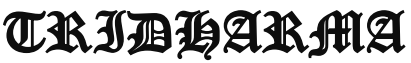

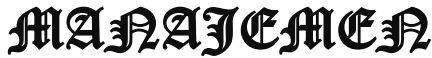

P-ISSN 2615-6849, E-ISSN 2716-070X

Jurnal ABDIMAS Vol. 1,No.2, Mei 2020,Hal(42-55)

@ Prodi Manajemen Fakultas Ekonomi Universitas Pamulang

Email: abdimasjurnal.unpam@gmail.com Telp: (021) 741-2566 memiliki peluang lebih besar memenangkan persaingan pasar, terutama pasar global. Hal ini dikarenakan sudah memiliki jaminan kualitas produk atau layanan yang ditawarkan, serta kepercayaan konsumen akan brand tersebut.

Sertifikasi ISO sebagai standar perusahaan akan memberikan beberapa manfaat, antara lain meningkatkan kredibilitas perusahaan serta kepercayaan pelanggan, jaminan kualitas dengan standar internasional, menghemat biaya, mengoptimalkan kinerja karyawan dan meningkatkan image perusahaan.

Siapa yang mengeluarkan sertifikat ISO?

Meskipun ISO mengembangkan standar internasional, tetapi mereka tidak terlibat dalam proses sertifikasi dan tidak menerbitkan sertifikat. Sertifikasi dilakukan oleh lembaga/badan sertifikasi ISO eksternal, sehingga perusahaan atau organisasi tidak dapat disertifikasi langsung oleh ISO.

Perusahaan/organisasi yang akan melaksanakan sertifikasi sistem manajemen berstandar ISO, akan berusaha mencari badan sertifikasi ISO terbaik. Hal ini wajar mengingat ada banyak sekali badan sertifikasi yang menyediakan jasa sertifikasi ISO.

Badan Sertifikasi ISO adalah perusahaan atau badan usaha yang memiliki wewenang untuk menerbitkan sertifikat ISO yang dibuat sesuai dengan ketentuan International Organization for Standarization (ISO) yang berkedudukan di Jenewa, Swiss.

Setiap negara yang tergabung dalam ISO mempunyai hak untuk mengontrol penerbitan Sertifikat ISO melalui suatu lembaga nasional yang memiliki kewenangan mengurusi masalah sertifikasi dan akreditasi.Lembaga ini di Indonesia disebut Komite Akreditasi Nasional (KAN). Tugas utama lembaga ini adalah untuk memberikan akreditasi terhadap berbagai lembaga lain yang berhubungan dengan penilaian kesesuaian.
Salah satu contoh badan sertifikasi ISO di Indonesia yang sudah mempunyai lisensi KAN adalah Sucofindo.

Sesuaikan Standard ISO Dengan Karakteristik Perusahaan

Dalam memilih jasa dari lembaga sertifikasi ISO tergantung dari karakteristik dan tujuan perusahaan/organisasi yang akan melakukan sertifikasi. Perusahaan harus teliti dalam memilih badan sertifikasi ISO agar relevan dengan visi dan misi perusahaan. Beberapa kriteria yang bisa membantu bagaimana memilih badan sertifikasi ISO yang baik antara lain : mempunyai sertifikasi dan akreditasi KAN yang masih berlaku, berpengalaman dalam bidang yang relevan, sesuai ekspektasi pelanggan, mempunyai reputasi yang baik, mempunyai sumber daya auditor yang jelas dan handal, tarif sesuai dengan ketentuan dan transparan.Jadi dalam memilih badan sertifikasi ISO harus relevan dan sesuai dengan ketentuan yang ada di

Indonesia maupun di dunia internasional.Ada beberapa standar ISO yang diterapkan di berbagai perusahaan. Antara lain Sistem Manajemen Mutu ISO 9001, Sistem Manajemen Lingkungan ISO 14001, Sistem Manajemen Resiko ISO 31000, dan lain-lain. Dalam hal ini yang berkaitan erat dengan dasar dasar sistem manajemen mutu adalah ISO 9001 tahun 2015.ISO 9001 tahun 2015 adalah standar manajemen mutu yang diakui secara internasional yang merupakan tolak ukur global untuk sistem manajemen mutu. Seiring dengan perkembangan global saat ini banyak sekali perusahaan yang ingin mengimplementasikan dan mendapatkan sertifikat ISO, terutama sertifikat ISO 9001.

6. Prinsip Manajemen Mutu ISO 9001:2015 adalah sebagai berikut:

1. Fokus Pelanggan

Fokus utama dari organisasi manapun adalah untuk memenuhi dan melampaui harapan dan kebutuhan pelanggan. Ketika suatu organisasi dapat memahami dan memenuhi 


\section{JURNAL ABDIMAS

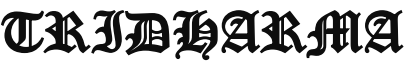

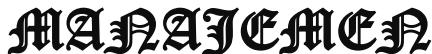

P-ISSN 2615-6849, E-ISSN 2716-070X

Jurnal ABDIMAS Vol. 1,No.2, Mei 2020,Hal(42-55)

@Prodi Manajemen Fakultas Ekonomi Universitas Pamulang

Email: abdimasjurnal.unpam@ gmail.com Telp: (021) 741-2566 kebutuhan pelanggan saat ini dan masa depan, maka akan menghasilkan loyalitas pelanggan, yang pada gilirannya meningkatkan pendapatan.

Bisnis ini juga bisa mendapatkan peluang pelanggan baru dan memuaskan mereka. Ketika proses bisnis lebih efisien, kualitas lebih tinggi maka lebih banyak pelanggan yang puas.

2. Kepemimpinan

Pada proses manajemen hal yang berkaitan dengan kepemimpinan sangat disoroti. Kepemimpinan yang baik menghasilkan kesuksesan organisasi.Pada kepemimpinan yang hebat mampu membangun persatuan dan tujuan di antara tenaga kerja dan pemegang saham.Menciptakan budaya perusahaan yang berkembang memberikan lingkungan internal yang memungkinkan karyawan untuk sepenuhnya memanfaatkan potensi mereka dan terlibat aktif dalam mencapai tujuannya.

Para pemimpin harus melibatkan karyawan dalam menetapkan tujuan dan sasaran organisasi yang jelas.Ini memotivasi karyawan, yang dapat secara signifikan meningkatkan Produktivitas dan loyalitas mereka.

3. Keterlibatan Orang

Keterlibatan staf adalah prinsip fundamental lainnya.Manajemen melibatkan staf dalam menciptakan dan memberikan nilai apakah mereka penuh waktu, paruh waktu, outsourcing atau di-rumah.Organisasi harus mendorong karyawan untuk terus meningkatkan keterampilan mereka dan menjaga konsistensi.

Prinsip ini juga melibatkan pemberdayaan karyawan, melibatkan mereka dalam pengambilan keputusan dan mengakui pencapaian mereka.Ketika orang dihargai, mereka bekerja dengan potensi terbaiknya karena hal itu meningkatkan kepercayaan diri dan motivasi mereka.Ketika karyawan sepenuhnya terlibat, itu membuat mereka merasa diberdayakan dan bertanggung jawab atas tindakan mereka.

4. Pendekatan Proses

Pada pendekatan ini menekankan pada pencapaian efisiensi dan efektivitas dalam proses organisasi. Pendekatan ini mensyaratkan pemahaman bahwa proses yang baik menghasilkan peningkatan konsistensi, kegiatan yang lebih cepat, pengurangan biaya, pengurangan pembuangan limbah dan peningkatan berkelanjutan.

Suatu organisasi ditingkatkan ketika pemimpin dapat mengelola dan mengendalikan input dan output dari suatu organisasi, serta proses yang digunakan untuk menghasilkan dan memaksimalkan output.

5. Peningkatan Berkesinambungan

Setiap organisasi harus mempunyai tujuan untuk terlibat aktif dalam perbaikan berkelanjutan. Bisnis yang meningkat terus mengalami peningkatan kinerja, fleksibilitas organisasi, dan peningkatan kemampuan untuk mendapatkan peluang baru. Bisnis harus dapat menciptakan proses baru secara berkelanjutan dan beradaptasi dengan kondisi dan situasi pasar yang selalu berubah.

6. Pengambilan Keputusan Berbasis Bukti

Pendekatan logis, berdasarkan data dan analisis, adalah naluri bisnis yang baik. Bisnis harus mengadopsi pendekatan faktual untuk pengambilan keputusan.Bisnis yang membuat keputusan berdasarkan data yang diverifikasi dan dianalisis memiliki pemahaman yang lebih baik tentang pasar. Mereka mampu melakukan tugas yang memberikan hasil yang diinginkan dan bahkan membenarkan keputusan masa lalu mereka.

Pengambilan keputusan faktual sangat penting untuk membantu memahami 


\section{JURNAL ABDIMAS

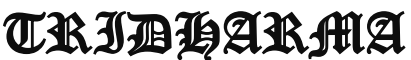

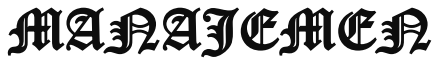

P-ISSN 2615-6849, E-ISSN 2716-070X

Jurnal ABDIMAS Vol. 1,No.2, Mei 2020,Hal(42-55)

@Prodi Manajemen Fakultas Ekonomi Universitas Pamulang

Email: abdimasjurnal.unpam@gmail.com Telp: (021) 741-2566 hubungan sebab-akibat dari berbagai hal dan bahkan menjelaskan potensi hasil dan konsekuensi yang tidak diinginkan.

7. Manajemen Hubungan

Manajemen hubungan adalah tentang menciptakan hubungan yang saling menguntungkan dengan semua pihak yang berkepentingan, termasuk pemasok dan pengecer.Berbagai pihak yang berkepentingan dapat memengaruhi kinerja perusahaan.

Organisasi harus mengelola proses rantai pasokan dengan baik dan mempromosikan hubungan antara organisasi dan pemasoknya untuk mengoptimalkan dampaknya terhadap kinerja perusahaan. Ketika suatu organisasi mengelola hubungannya dengan pihak-pihak yang berkepentingan dengan baik, maka lebih mungkin untuk mencapai kolaborasi bisnis yang berkelanjutan.

\section{Manfaat Manajemen Mutu}

1. Membantu organisasi mencapai konsistensi yang lebih besar dalam tugas dan kegiatan yang terlibat dalam produksi produk dan layanan.

2. Meningkatkan efisiensi dalam proses, mengurangi pemborosan dan meningkatkan penggunaan waktu dan sumber daya lainnya.

3. Membantu meningkatkan kepuasan pelanggan.

4. Memungkinkan bisnis untuk memasarkan bisnis mereka secara efektif dan mengeksploitasi pasar baru.

5. Memudahkan bisnis untuk mengintegrasikan karyawan baru dan dengan demikian membantu bisnis mengelola pertumbuhan dengan lebih mulus.

6. Memungkinkan bisnis untuk terus meningkatkan produk, proses, dan sistem mereka.

\section{Pengenalan ISO 9001:2008}

ISO 9001:2008 telah diadopsi menjadi SNI ISO 9001:2008 dan ditetapkan oleh Kepala BSN
Nomor.127/KEP/BSN/12/2008 tanggal 31 Desember 2008.Metode adopsi SNI tersebut dengan menggunakan cetak ulang sehingga masih menggunakan bahasa Inggris. Terbitan ini merupakan terjemahan SNI ISO 9001:2008 ke dalam bahasa Indonesia sehingga terbitan ini merupakan pendukung dari SNI ISO 9001:2008, sehingga yang menjadi acuan utama adalah SNI ISO 9001:2008. Dan apabila terjadi perbedaan pemahaman terhadap terjemahan standar ini dianjurkan untuk mengacu kepada SNI ISO 9001:2008.

Beberapa dokumen ISO yang diacu dalam Standar ini telah diadopsi menjadi SNI, yaitu:

1. ISO 9000:2005, Quality management systems - Fundamentals and vocabulary diadopsi menjadi SNI 199000-2008 Sistem manajemen mutu Dasar-dasar dan kosa kata.

2. ISO 9004:2000, Quality management systems - Guidelines for performance improvements diadopsi menjadi SNI 19-9004-2002 Sistem manajemen mutu - Panduan untuk perbaikan kinerja

3. ISO 19011:2002, Guidelines for quality and/or environmental management systems auditing diadopsi menjadi SNI 19-19011-2005 Panduan audit sistem manajemen mutu dan/atau lingkungan

4. ISO 14001:2004, Environmental management systems - Requirements with guidance for use diadopsi menjadi SNI 19-14001-2005 Sistem manajemen lingkungan - Persyaratan dan panduan penggunaan.

Prinsip manajemen mutu diturunkan dari pengalaman dan pengetahuan kolektif para pakar internasional yang terlibat dalam komite teknis (technical committee, TC) penyusun ISO 9001. Prinsip-prinsip ini dapat digunakan oleh manajemen senior sebagai kerangka kerja untuk memandu organisasi mereka menuju perbaikan kinerja(Ivan Lanin, 2017): 


\section{JURNAL ABDIMAS

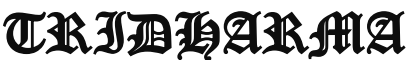

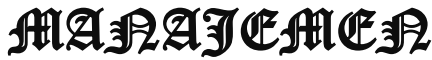

P-ISSN 2615-6849, E-ISSN 2716-070X

Jurnal ABDIMAS Vol. 1,No.2, Mei 2020,Hal(42-55)

@Prodi Manajemen Fakultas Ekonomi Universitas Pamulang

Email: abdimasjurnal.unpam@gmail.com Telp: (021) 741-2566

\section{Fokus pada Pelanggan (Customer Focus)}

Fokus utama manajemen mutu adalah guna memenuhi persyaratan pelanggan dan untuk berupaya melebihi harapan pelanggan.

Kesuksesan berkesinambungan dicapai saat organisasi menarik dan mempertahankan kepercayaan pelanggan dan pemangku kepentingan lain. Tiap aspek interaksi pelanggan memberikan peluang untuk menciptakan nilai lebih kepada pelanggan. Pemahaman kebutuhan saat ini dan masa depan dari pelanggan memberikan sumbangsih kepada kesuksesan berkesinambungan dari organisasi.

\section{Prinsip ISO 9001}

Tindakan yang dapat dilakukan untuk meningkatkan fokus pada pelanggan:
1. Identifikasikan langsung dan tidak langsung

2. Pahami kebutuhan dan harapan tiap pelanggan pada saat ini dan masa depan

3. Kaitkan sasaran organisasi dengan kebutuhan dan harapan pelanggan

4. Komunikasikan kebutuhan dan harapan pelanggan di seluruh organisasi

5. Rencanakan, rancang, kembangkan, hasilkan, berikan, dan dukung produk dan layanan untuk memenuhi kebutuhan dan harapan pelanggan

6. Ukur dan pantau kepuasan pelanggan serta ambil tindakan yang sesuai

7. Tentukan dan tanggapi kebutuhan dan harapan pemangku kepentingan yang relevan, yang dapat memengaruhi kepuasan pelanggan
8. Kelola hubungan dengan pelanggan untuk mencapai kesuksesan yang berkesinambungan

Tindakan yang dapat dilakukan untuk meningkatkan perbaikan:

1. Dorong penetapan sasaran perbaikan pada semua tingkatan organisasi

2. Didik dan latih orang pada semua tingkatan tentang cara penerapan alat dan metodologi dasar untuk mencapai sasaran perbaikan

3. Pastikan kompetensi SDM untuk menjalankan proyek perbaikan

4. Kembangkan proses untuk menerapkan proyek perbaikan di seluruh organisasi

5. Lacak, tinjau, dan audit perencanaan, penerapan, penyelesaian, dan hasil proyek perbaikan

6. Integrasikan pertimbangan perbaikan dalam pengembangan produk, layanan, dan proses yang baru atau yang diubah

7. Akui dan hargai perbaikan

2. Pengambilan Keputusan Berbasis Bukti (Evidence-Based Decision Making)

Keputusan berdasarkan analisis dan evaluasi data dan informasi lebih berpeluang untuk mencapai hasil yang diinginkan. Pengambilan keputusan dapat menjadi proses yang kompleks dan selalu melibatkan ketidakpastian. Proses ini kadang melibatkan beragam jenis dan sumber masukan, serta interpretasi terhadap masukan tersebut, yang dapat bersifat subjektif. Diperlukan pemahaman terhadap hubungan sebab dan akibat serta potensi dampak yang tidak diinginkan.Fakta, bukti, dan analisis data meningkatkan objektivitas dan kepercayaan dalam pengambilan keputusan. Prinsip ISO 9001

Tindakan yang dapat dilakukan untuk meningkatkan pengambilan keputusan berbasis bukti:

1. Tentukan, ukur, dan pantau indikator utama terhadap kinerja organisasi

2. Sediakan data yang diperlukan bagi orang-orang yang relevan 


\section{JURNAL ABDIMAS

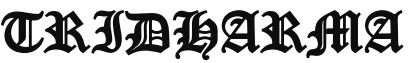

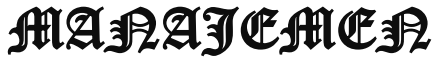

P-ISSN 2615-6849, E-ISSN 2716-070X

Jurnal ABDIMAS Vol. 1,No.2, Mei 2020,Hal(42-55)

@Prodi Manajemen Fakultas Ekonomi Universitas Pamulang

Email: abdimasjurnal.unpam@ gmail.com Telp: (021) 741-2566
3. Pastikan bahwa data dan informasi cukup tepat, andal, dan aman

4. Analisis dan evaluasi data dan informasi dengan metode yang tepat

5. Pastikan kompetensi SDM untuk menganalisis dan mengevaluasi data sesuai kebutuhan

6. Ambil keputusan dan tindakan berdasarkan bukti yang diseimbangkan pengalaman dan intuisi

7. Manajemen Hubungan (Relationship Management)

Guna mencapai kesuksesan yang berkesinambungan, organisasi mengelola hubungannya dengan para pemangku kepentingan, seperti pemasok.Pemangku kepentingan memengaruhi kinerja organisasi.Pengelolaan hubungan dengan para pemangku kepentingan ini mengoptimalkan pengaruh mereka terhadap kinerja organisasi.Manajemen hubungan dengan pemasok dan jaringan mitra seringkali memiliki kepentingan tertentu.

Tindakan yang dapat dilakukan untuk meningkatkan manajemen hubungan:

1. Tentukan pemangku kepentingan yang relevan (msl pemasok, mitra, pelanggan, investor, karyawan, atau komunitas) serta hubungan mereka dengan organisasi

2. Tentukan dan prioritaskan hubungan dengan pemangku kepentingan yang perlu dikelola

3. Ciptakan hubungan yang menyeimbangkan manfaat jangka pendek dengan jangka panjang

4. Kumpulkan dan bagikan informasi, keterampilan, dan sumber daya dengan pemangku kepentingan yang relevan

5. Ukur kinerja dan berikan umpan balik kinerja kepada pemangku kepentingan sesuai kebutuhan guna meningkatkan inisiatif perbaikan
6. Jalankan aktivitas pengembangan dan perbaikan kolaboratif dengan pemasok, mitra, dan pemangku kepentingan lain

7. Dorong dan hargai perbaikan dan pencapaian dari pemasok dan mitra.

\section{METODE PELAKSANAAN}

Adapun metode kegiatan pada PKM ini diberikan dengan cara sebagai berikut:

a) Pre-post test diikuti dengan Pengajaran atau presentasi (Powerpoint) di kelas

b) Pemutaran video dan animasi

c) Studi kasus/quiz, games yang mengandung materi PKM

d) Diskusi dan tanya jawab dan simulasi

e) Final Test

\section{HASIL DAN PEMBAHASAN}

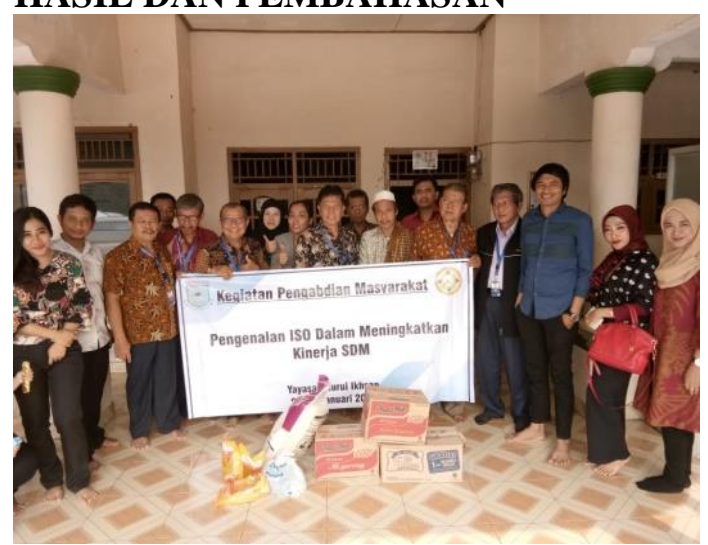

Sumber: hasil dokumentasi saat PKM

A. Standar mutu Yayasan Pondok Pesantren Dan Panti Asuhan Nurul Ihsan Kampung Mononggor.

Perkembangan masyarakat yang semakin kompetitif menuntut setiap orang untuk berkompetisi secara sehat. Demikian halnya dengan sebuah lembaga termasuk lembaga pendidikan islam seperti halnya dengan pesantren kompetisi untuk merebut pasar menunut setiap lembaga untuk mengedepankan kualitas dalam proses menejerialnya dalam pembelajarannya. Dalam kaitannya dengan persoalan kualitas ini, sekarang telah berkembang sebuah pendekatan, 


\section{JURNAL ABDIMAS

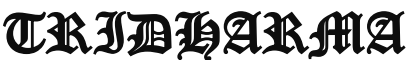

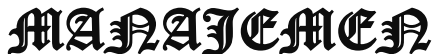

P-ISSN 2615-6849, E-ISSN 2716-070X

Jurnal ABDIMAS Vol. 1,No.2, Mei 2020,Hal(42-55)

@Prodi Manajemen Fakultas Ekonomi Universitas Pamulang

Email: abdimasjurnal.unpam@ gmail.com Telp: (021) 741-2566 khususnya dalam proses menejerial, yaitu apa yang disebut Total Quality Management (TQM).

Total Qualaity Management (TQM) dapat digunakan untuk menggambarkan dua gagasan yang agak berbeda tetapi saling berkaitan.Pertama, dalah filsafat perbaikan terus menerus.Kedua, arti yang salaing berkaitan menggunakan TQM untuk menggambarkan alat dan teknik, seperti brainstorming dan analisis lapangan, dimana digunakan untuk meletakan perbaikan kualitas kedalam tindakan.

$$
\text { Istilah kualitas menjadi }
$$

menderita karena sering digunakan untuk menggambarkan lambang-lambang seperti kecantikan, kebaikan, kemahalan, kesegaran dan diatas semua itu, kemewahan. Karena itu, kualitas menjasi konsef yang sulit dimengerti dan hampir tidak mungkin ditangani.Bagaimana mungkin menangani sesuatu yang tidak jelas dan mempunyai arti demikian banyak. Dalam kontek manajeman kualitas, Quality itu adalah goodness of product, ini dalam perspektif absolut mind goodness of product, biasanya produk yang bagus akan berimplikasi pada harga.

Kualitas (Quality) sering disamaartikan dengan mutu.Kualitas sebenarnya telah menjadi bagian dari kehidupan sehari-hari.Istilah dalam "mutu" merupakan padanan dari istilah dalam bahasa inggris, yakni quality, artinya, goodness or worth.Dengan demikian, secara definitif istilah mutu dapat diartikan sebagai kebaikan atau nilai. Pada mulanya, istilah mutu banyak digunakan dalam bidang ekonomi, khususnya dalam organisasi industri, dimana mutu diartikan sebagai karakteristik produk/jasa yang ditentukan oleh pihak pelanggan, dan diperoleh melalui pengukuran proses serta perbaiakn secara berkesinambungan. Akan tetapi, sampai sekarang, baik didunia industri barang atau jasa, belum ada definisi yang sama tentang kualitas. Goetsch dan Davis mengibaratkan bahwa kualitas seperti halnya pornografi, yaitu sulit didefinisikan, tetapi fenomenanya atau tanda-tandanya dapat dilihat dan dirasakan dalam kehidupan nyata.Setiap orang dan organisasi memiliki pengertian kualitas yang berbeda-beda. Misalnya Fred Smith, CEO General Expres mengartikan kualitas adalah kinerja standar yang diaharapkan oleh pemakai produk atau jasa (customer).

Menurut General Servis Administration (GSA) kualitas adalah pertemuan kebutuhan customer pada awal mula dan setiap saat. Sedangkan Ann Komariah dan Cepi Triatna mendefinisikan mutu secara esensial digunakan untuk menunjukan kepada suatu ukuran penilaian atau penghargaan yang diberikan atau dikenakan kepada barang (product) dan / atau jasa (service) tertentu berdasarkan pertimbangan obyektif datas bobot dan kinerjanya. Sementara menurut W. Edward Deming, salah seorang pioner kualitas menyatakan bahwa kualitas itu memiliki banyak kriteria yang selalu berubah. Namun demikian, definisi kualitas yang diterima secara umum mencakup elemenelemen berikut:

a) Mempertemukan harapan pelanggan (customer),

b) Menyangkut aspek produk, servis, orang, proses dan lingkungan,

c) Kriteria yang selalu berkembang yang berarti bahwa sebuah produk sekarang termasuk berkualitas, tetapi di lain waktu mungkin tidak lagi berkualitas. 


\section{JURNAL ABDIMAS

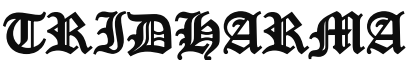

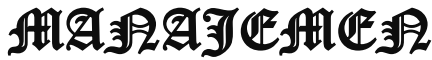

P-ISSN 2615-6849, E-ISSN 2716-070X

Jurnal ABDIMAS Vol. 1,No.2, Mei 2020,Hal(42-55)

@ Prodi Manajemen Fakultas Ekonomi Universitas Pamulang

Email: abdimasjurnal.unpam@ gmail.com Telp: (021) 741-2566
Jadi kualitas adalah sesuatu yang dinamis yang selalu diasosiasikan dengan produk, serbis, orang, proses, dan lingkungan. Menurut Edward Sallis, kualitas itu memang sesuatu yang tarik menarik antara sebagai konsef yang absolut dan relatif. Namun, ia menegaskan bahwa kualitas sekaran ini lebih diguanakan sebagai konsef yang absolut. Karena itu, kualitas mempunyai kesamaan arti dengan kebaikan, keindahan, dan kebenaran; atau kesrasian yang tidak ada kompromi. Standar kualitas itu meliputi dua, yaitu; kualitas yang didasarkan pada standar produk/jasa dan kualitas yang didasarkan pada pelanggan (customer) .kualitas yang didasarkan pada produk/jasa, memiliki beberapa kualifikasi: 1. Sesuai dengan spesifikasi.2. sesuai dengan maksud dan kegunaanya, 3. Tidak salah atau cacat, dan 4. Benar pada saat awal dan pertamanya. Sementara itu, kualitas yang didasarkan pada customer, mempunyai kualifikasi; 1. Memuaskan pelanggan (customer satisfaction) 2 . Melebihi harapan pelanggan, dan 3 . Mencerahkan pelanggan. Sedangkan MN Nasution mensinyalir ada empat prinsif utama dalam Total Quality Management (TQM), yaitu: kepuasan pelanggan, respek terhadap setiap orang, menejemen berdasakan fakta, dan perbaikan berkesinambungan (ijudin, 2015).

B. Implementasi Standar ISO Dalam Meningkatkan Kinerja SDM Pada Yayasan Pondok Pesantren Dan Panti Asuhan Nurul Ihsan Kampung Mononggor.

Cara mengimplementasikannya adalah:

a. Implementasi perencanaan mutu (quality planning) pendidikan di Pondok Pesantren didasarkan pada dalil surat al-Nashr ayat 3 dengan cara mentasharufkan perencanaan mutu pendidikan dengan istilahtasbih. Maksudnya adalah perencanaan mutu pendidikan pesantren sebagai bentuk tasbih yaitu mengingat atau menetapkan standar mutu yang akan direncanakan. Aspek-aspek yang perlu direncanakan dalam rangka peningkatan mutu pendidikan pesantren adalah perlu dibuatkannya dokumen Rencana strategis (Renstra) oleh pesantren tersebut yang di dalamnya beriti: (1) Menetapkan visi misi pesantren; (2) Menetapkan tujuan dan sasaran; (3) Melakukan analisis SWOT; (4) Menetapkan strategi peningkatan mutu; (5) Merencanakan profile ideal pondok pesantren; (6) Merencanakan pengembangan pondok pesantren; dan (7) Menetapkan langkah-langkah strategi pengembangan.

b. Implementasi pengendalian mutu (quality control) pendidikan di Pondok Pesantren didasarkan juga pada ayat 3 surat al-Nashr. Pengendalian mutu di pesantren tersebut diistilahkan dengan tahmid. Maksudnya adalah bahwa dalam pengendalian mutu perlu didukung oleh unsur-unsur yang terpuji (tahmid) sebagai pengendalinya, baik SDM pengendalinya, pembiayaannya, sarana-prasarana, maupun aspek lainnya. Aspek-aspek mutu yang dikendalikan di pesantren tersebut meliputi: (1) Penataan ulang pesantren (pesantren review); (2) Penjaminan mutu pesantren (quality assurance);

Pengawasan mutu pesantren (quality control); dan (4) Benchmarking. Salah satu cara pengendalian mutunya adalah dengan membuka pendidikan salafiyah, pendidikan formal sekolah, dan pendidikan vocasional di lingkungan pesantren. Penataan ulang kelembagaan ini menjadi pintu masuk bagi pesantren tersebut dalam membuka peluang 


\section{JURNAL ABDIMAS

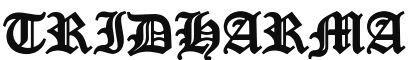

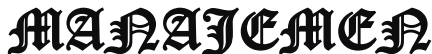

P-ISSN 2615-6849, E-ISSN 2716-070X

Jurnal ABDIMAS Vol. 1,No.2, Mei 2020,Hal(42-55)

@ Prodi Manajemen Fakultas Ekonomi Universitas Pamulang

Email: abdimasjurnal.unpam@gmail.com Telp: (021) 741-2566 perubahan pada sektor-sektor lain, terutama dalam mengantisipasi perubahan tuntutan masyarakat terhadap pendidikan yang menghendaki lebih berperan serta dalam menciptakan kualitas SDM lulusan. Melalui perubahan ini akan tercipta kualitas lulusan pesantren ahli agama (mutafaqqih fiddîn), ahli fikir (mutakallimin), dan mandiri (mutaqawwimin) melalui ketiga jenis pendidikan yang diselenggarakan di Pesantren Sukahideng.

c. Implementasi perbaikan mutu (quality improvement) pendidikan di Pondok Pesantren didasarkan atas dalil surat al-Nashr ayat 3 yang mentasharufkan perbaikan mutu dengan istilah istighfar (taubat). Maksudnya, perbaikan mutu pendidikan (quality improvement)diarahkan pada upaya penyempurnaan pendidikan berupa tindakan yang dilakukan setelah data atau informasi hasil pengendalian diperoleh, dianalisis, dan dievaluasi untuk memperbaiki dan menyempurnakan dokumen

\section{KESMIPULAN}

Berdasarkan pembahasan di atas maka dapat disimpulkan bahwa manajemen mutu pesantren merupakan suatu proses yang meliputi serangkaian tindakan, dimana unsur-unsur dan fungsifungsi manajemen dipekerjakan se-efisien dan efektif mungkin dengan bantuan orang lain yang bertujuan untuk mencapai goals dan sasaran yang telah ditentukan pesantren sesuai dengan kebutuhan dan kepuasan pelanggan serta berdasarkan atau melebihi standar- kan yang telah ditetapkan mulai dari input, proses, sampai pada out- put pendidikan.

Konsep manajemen mutu pesantren berkaitan dengan kegiat- an optimalisasi fungsi-fungsi manajemen dalam mengelola mutu pesantren mulai dari perencanaan strategis mutu, riset pasar, analisis SWOT, peristiwa kunci, rencana strategis, mengembangkan strategi institusional jangka panjang, kebijakan mutu dan rencana mutu, biaya dan keuntungan mutu, biaya pencegahan dan kegagalan, sampai pada pengawasan dan evaluasi serta control mutu. Kriteria pesantren yang bermutu antara lain; 1) lingkungan pendidikan yang aman dan tertib, 2) perumusan visi, misi dan target mutu yang jelas, 3) kepemimpinan pendidikan yang andal, 4) harapan prestasi dan output yang tinggi, 5) pengembangan dan penigkatan kualifikasi, 6) evaluasi belajar yang efektif dan efisien, dan 7) interaksi komunikatif antara lembaga pendidikan, orangtua dan masyarakat.

\section{DAFTAR PUSTAKA}

Admin, 2019, "Manajemen Mutu: Pengertian, Tujuan, Proses, Manfaat Disertai ISO, Admin Jurnal Manajemen",https://jurnalmanajemen.com/ manajemen-mutu/ (diakses Hari Jumat, 20 Desember 2019).

Hari Sudrajat, 2005, Manajemen Peningkatan Mutu Berbasis Sekolah Peningkatan Mutu Pendidikan Melalui Implementasi KBK, Bandung: CiptaCekas Grafika.

Ijudin, 2015, Pengembangan Konsep Mutu Pendidikan Pondok Pesantren, Jurnal Pendidikan Universitas Garut Fakultas Pendidikan Islam dan Keguruan Universitas Garut ISSN: 1907-932X.

Ivan Lanin, 2017, "7 Prinsip Manajemen Mutu ISO 9001:2015" https://ipqi.org/prinsip-iso-9001/ (diakses hari Minggu 30 Desember 2019)

J.M. Juran, 1995, Merancang Mutu, Terjemah Bambang Hartono dari Juran on Quality By Design, Jakarta: Binawan Pressido.

Pasaribu, V. L. D., Agrasadya, A., Shabrina, N., \& Krisnaldy, K. (2020). 


\section{JURNAL ABDIMAS

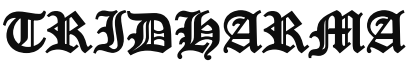

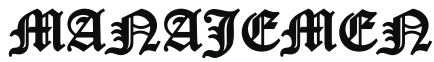

P-ISSN 2615-6849, E-ISSN 2716-070X

Jurnal ABDIMAS Vol. 1,No.2, Mei 2020,Hal(42-55)

@Prodi Manajemen Fakultas Ekonomi Universitas Pamulang

Email: abdimasjurnal.unpam@gmail.com Telp: (021) 741-2566
MENJADI ENTERPRENEUR MUDA YANG MEMILIKI JIWA LEADERSHIP UNTUK MENGHADAPI MASA DEPAN. Abdi Laksana, 1(1).

Pasaribu, V. L. D., Elburdah, R. P., Sudarso, E., \& Fauziah, G. (2020). PENGGUNAAN MANAJEMEN WAKTU TERHADAP PENINGKATAN PRESTASI BELAJAR DI SMP ARAISIYAH. Jurnal ABDIMAS, 1(1).

Pasaribu, V. L. D., Susanti, F., \& Hartuti, E. T. K. (2019). MEMOTIVASI SISWA DAN SISWI SMK LETRIS INDONESIA DI DALAM MENENTUKAN PILIHAN UNTUK MELANJUTKAN PENDIDIKAN ATAU BEKERJA SETELAH LULUS SEKOLAH. Jurnal Pengabdian Dharma Laksana, 1(2), 161172.

Poerwanto G, Hendra, "Plan-Do-CheckAct (PDCA)", https://sites.google.com/site/kelo lakualitas/PDCA (diakses hari Jumat, 20 Desember, 2019)
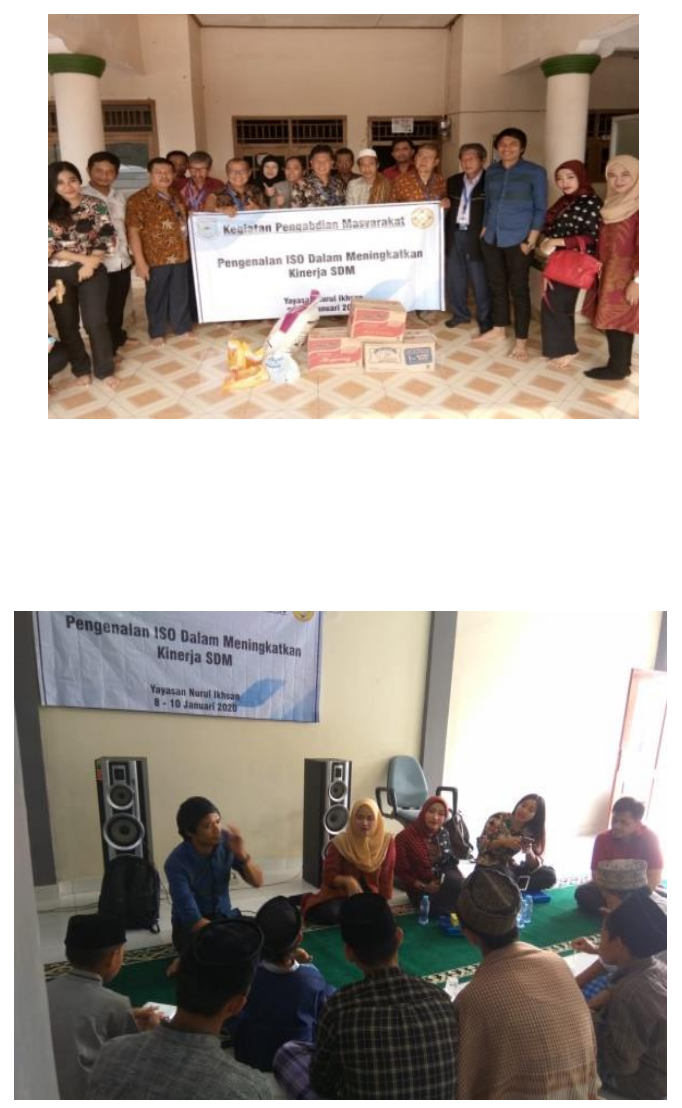

\section{DOKUMENTASIFOTO KEGIATAN}

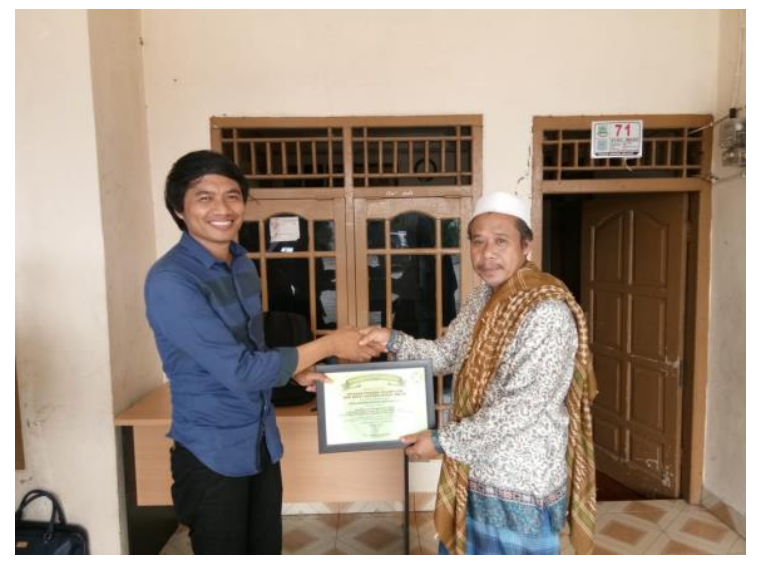

